\title{
Rancang Bangun Sistem Informasi Akuntansi di STIKI Copy Center
}

\author{
Lucky Hardiyanti Kartika Haris*¹, Dewa Putu Yudhi Ardiana ${ }^{2}$, I Putu Agus Eka Darma \\ Udayana $^{3}$ \\ ${ }^{1,2,3}$ Program Studi Teknik Informatika, STMIK STIKOM Indonesia, Bali, Indonesia \\ e-mail: *11 khairunnisa.devanti@gmail.com, ${ }^{2}$ gede.suka@gmail.com, ${ }^{3}$ eka.agus@gmail.com
}

\begin{abstract}
Abstrak
Abstrak; STIKI Copy Center merupakan salah satu tempat usaha yang menyediakan pelayanan print, fotocopy, scan dan menjual alat tulis kantor. Proses pembuatan laporan keuangan yang terjadi pada STIKI Copy Center masih belum sesuai dengan laporan keuangan yang seharusnya dan masih menggunakan Ms.Excel yang membuat owner merasa kesulitan dalam proses pemberian rumus saat melakukan perhitungan. Laporan keuangan yang dibuat pada Ms.Excel bisa saja dimanipulasi oleh seseorang atau owner bisa saja melakukan penginputan dengan data yang sama sehingga dapat menyebabkan redudancy dan juga dapat menyebabkan ketidaksesuaian data dan data tersebut bisa saja hilang atau terhapus jika terinfeksi oleh virus atau tanpa sengaja dihapus. Penelitian ini bertujuan untuk merancang dan membangun sistem informasi akuntansi di STIKI Copy Center yang dimulai dengan tahapan pengidentifikasian masalah, melakukan pengumpulan data, analsisi pemodelan sistem dengan menggunakan UML, membangun sistem dengan menggunakan framework laravel dan database MySQL. Adapun hasil dari penelitian ini ialah aplikasi keuangan berbasis website yang akan memproses transaksi pemasukan dan pengeluaran dan mencetak laporan jurnal umum, neraca, laporan laba rugi, laporan perubahan modal dan juga dilengkapi dengan grafik pemasukan untuk setiap bulannya. Dari hasil pengujian dengan menggunakan metode black box testing dapat diketahui bahwa sistem sudah berjalan dengan baik sesuai dengan yang diharapkan.
\end{abstract}

Kata kunci-Laporan keuangan, framework laravel, website

\begin{abstract}
Abstract STIKI Copy Center is one place of business that provides print, copy, scan and sells office stationery services. Financial reporting process that occurs in STIKI Copy Center is still not in accordance with the financial statements should be and still use Ms. Excel which makes the owner feel difficulty in the process of calculating the current formula. The financial statements made at Ms.Excel can be manipulated by someone or the owner can do inputting with the same data so that it can cause redundancy and can also cause incompatibility of data and data that could be lost or deleted if infected by a virus or accidentally deleted.

This research aims to design and build an accounting information system at STIKI Copy Center which begins with the stages of identifying problems, conducting data collection, analyzing system modeling using UML, building systems using the laravel framework and MYSQL database. The results of this research are financial applications based website that will process the transaction income and expenses and print reports general ledger, balance sheet, income statement, statement of changes in capital and is also equipped with a revenue graph for each month. From the test results by using black box testing can be seen that the system has been going well as expected
\end{abstract}

Keywords - Financial reports, laravel framework, website

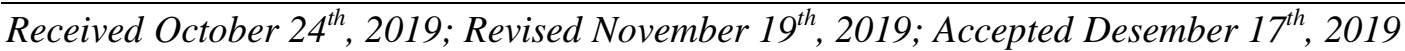




\section{PENDAHULUAN}

Perkembangan teknologi informasi sangat membantu perusahaan dalam menjalankan proses bisnis, baik itu perusahaan yang berskala kecil maupun yang berskala besar. Kini hampir semua perusahaan telah menerapkan teknologi untuk meningkatkan layanan bisnis yang dikelola dan mempermudah proses bisnis yang terjadi di perushaan tersebut. Salah satu tempat usaha yang sudah mengikuti perkembangan teknologi saat ini ialah STIKI Copy Center. STIKI Copy Center merupakan salah satu tempat usaha yang menyediakan pelayanan print, fotocopy, scan dan menjual alat tulis kantor. STIKI Copy Center terletak di Jl.Tukad Pakerisan dan lebih tepat lagi terletak di dalam area kampus STIKI Indonesia.

STIKI Copy Center sudah mulai menerapkan teknologi dalam proses penjualannya. Dalam mengelola proses penjualannya STIKI Copy Center menggunakan sistem yang dapat membantu karyawan dan owner dalam melakukan proses pembuatan laporan penjualan yang biasanya dibuat setelah pergantian shift. Laporan penjualan tersebut akan dicetak oleh karyawan dan akan diberikan kepada owner untuk membuat laporan keuangannya. Hal tersebut dilakukan karena pada sistem penjualan yang tersedia pada STIKI Copy Center belum menghasilkan laporan yang sesuai dengan laporan keuangan yang seharusnya. Sehingga owner membuat kembali laporan keuangannya secara terpisah.

Setelah owner mendapatkan laporan penjualan tersebut, selanjutnya owner akan membuat laporan keuangannya. Adapun laporan keuangan yang dibuat oleh owner ialah berupa laporan debet kredit yang menyerupai laporan jurnal umum dan owner juga membuat laporan untuk setiap akhir tahunnya. Namun laporan keuangan yang dibuat masih menggunakan Microsoft Excel. Berdasarkan hasil wawancara dan observasi yang dilakukan oleh penulis didapatkan bahwa owner merasa kesulitan dalam proses pembuatan laporan keuangan yang dibuat dengan menggunakan Microsoft Excel, hal ini dikarenakan owner kesulitan dalam proses pemberian rumus saat melakukan perhitungan. Laporan keuangan yang dibuat menggunakan Microsoft Excel bisa saja dimanipulasi oleh seseorang dan data tersebut bisa saja hilang atau terhapus jika terinfeksi oleh virus atau tanpa sengaja dihapus. Selain permasalahan tersebut, owner bisa saja melakukan penginputan dengan data yang sama sehingga dapat menyebabkan redudancy dan juga dapat menyebabkan ketidaksesuaian data. Selain permasalahan yang telah dijelaskan diatas, berdasarkan observasi yang dilakukan oleh penulis didapatkan bahwa laporan keuangan yang dibuat masih belum sesuai dengan standar yang seharusnya sehingga belum adanya kejelasan darimana saja sumber dana yang didapatkan.

Berdasarkan permasalahan diatas maka pada penelitian kali ini perlu adanya pengembangan sistem informasi yang mendukung proses pencatatan laporan keuangan, sehingga dapat menyajikan informasi keuangan untuk setiap tahunnya. Sistem ini merupakan sistem informasi akuntansi yang dapat melakukan pengelolaan data pemasukan dan pengeluaran yang akan menghasilkan laporan jurnal umum, laporan neraca, laporan laba/rugi dan laporan perubahan modal. Dengan adanya sistem informasi yang dirancang untuk menangani dan mengolah data menjadi informasi maka penulis bermaksud untuk merancang suatu sistem yang dapat memudahkan owner untuk membuat laporan keuangan. Adapun judul yang penulis berikan terhadap penelitian ini ialah "Rancang Bangun Sistem Informasi Akuntansi di STIKI Copy Center."

\section{METODE PENELITIAN}

Metode penelitian meliputi analisa permasalahan, arsitektur atau rancangan metode yang digunakan untuk menyelesaikan masalah.

\subsection{Penelitian Terdahulu}

Harap Penelitian terdahulu yang mendukung penelitian ini ialah [1] yang berjudul "Sistem Informasi Laporan Keuangan Pada Hattrick Center Berbasis Web". Penelitian ini

JSIKTI Vol. 2, No. 2, Desember 2019: $77-88$ 
dirancang hanya untuk mencakup proses manajemen keuangan dan menghasilkan laporan keuangan. Penelitian ini dapat melakukan pengolahan data akun, pengolahan data transaksi dan mengelola laporan sehingga dapat menghasilkan laporan jurnal, laporan penerimaan, pengeluaran dan laporan laba rugi yang diharapkan dapat meningkatkan mutu pelayanan dan dapat memudahkan dalam pencarian informasi keuangan pada Hattrick Center.

Penelitian lainnya ialah [2] dengan judul "Rancang Bangun Sistem Informasi Pengelolaan Keuangan Pada CV. Sinar Surya Transportasi Berbasis Website". Sistem informasi pengelolaan keuangan ini dirancang untuk memberikan gambaran sebuah model sistem informasi keuangan menggunakan layanan website dengan harapan pengguna pada perusahaan CV. Sinar Surya Transportasi dapat dengan mudah memperoleh akses pelayanan dan informasi seluruh kegiatan, khususnya dalam hal keuangan. Dengan adanya sistem ini pengguna bisa mengakses informasi secara online. Penelitian ini dapat melakukan pengolahan data akun, mengolah data pemasukan sewa, mengolah data jenis pengeluaran, mengolah data pengeluaran dan laporan, sehingga dapat menghasilkan informasi berupa laporan pemasukan, laporan pengeluaran, laporan laba rugi dan grafik statistik. Fitur yang terdapat pada penelitian ini ialah laba rugi.

Perbedaan penelitian saat ini dengan penelitian yang dilakukan oleh Putra ialah pada penelitian Putra tidak membahas tentang laporan neraca dan laporan perubahan modal sedangkan perbedaan penelitian saat ini dengan penelitian yang dilakukan oleh Setyadevi yaitu pada penelitian Setyadevi tidak membahas tentang laporan jurnal, laporan neraca dan laporan perubahan modal. Sistem yang dibangun dapat diakses oleh pemilik perusahaan dan informasi yang akan dihasilkan berupa laporan laba rugi perbulan, per tahun dan laporan perubahan modal.

Berdasarkan uraian tentang penelitian terdahulu yang telah dijabarkan, maka dapat disimpulkan bahwa dalam penelitian ini penulis menambahkan beberapa fitur yang menjadi perbedaan dari penelitian sebelumnya. Adapun fitur-fitur yang ada dalam penelitian ini ialah jurnal, neraca, laba rugi dan laporan perubahan modal

\subsection{Sistem}

Terdapat dua kelompok pendekatan di dalam pendefinisian sistem, yaitu kelompok yang menekankan pada prosedur dan kelompok yang menekankan pada elemen atau komponennya. Pendekatan yang menekankan pada prosedur mendefinisikan sistem sebagai suatu jaringan kerja prosedur-prosedur yang saling berhubungan, berkumpul bersama-sama untuk melakukan suatu kegiatan atau untuk menyelesaikan suatu sasaran tertentu. Sedangkan pendekatan sistem yang lebih menekankan pada elemen atau komponen mendefinisikan sistem sebagai kumpulan elemen yang berinteraksi untuk mencapai suatu tujuan tertentu. Kedua kelompok definisi ini adalah benar dan tidak bertentangan. Yang berbeda adalah cara pendekatannya [3], seperti halnya pada sistem pendukung keputusan, hasil yang diperoleh disajikan kepada pemegang keputusan atau pemilik [4,5].

Sistem adalah suatu jaringan kerja dari prosedur-prosedur yang saling berhubungan, berkumpul bersama-sama untuk melakukan kegiatan atau untuk melakukan sasaran yang tertentu [6]. Pendekatan sistem yang merupakan jaringan kerja dari prosedur lebih menekankan urutan-urutan operasi di dalam sistem.

Menyatakan bahwa sistem adalah suatu jaringan kerja dari prosedur-prosedur yang saling berhubungan, berkumpul bersama-sama untuk melakukan suatu kegiatan atau untuk menyelesaikan suatu sasaran yang tertentu $[7,8]$.

\subsubsection{Karakteristik Sistem}

Supaya sistem itu dikatakan sistem yang baik memiliki karakteristik yaitu [6]:

1. Komponen

Suatu sistem yang terdiri dari sejumlah komponen-komponen yang saling berinteraksi, yang 
artinya saling bekerja sama membentuk satu kesatuan. Komponen sistem terdiri dari komponen yang berupa subsistem atau bagian-bagian dari sistem.

2. Batasan sistem (Boundary)

Batasan sistem merupakan daerah yang membatasi antara suatu sistem dengan sistem yang lain atau dengan lingkungan luarnya. Batasan sistem ini memungkinkan suatu sistem dengan sistem dipandang sebagai suatu kesatuan. Batsan suatu sistem menunkukkan ruang lingkup (scope) dari sistem tersebut.

3. Lingkungan Luar Sistem (Environment)

Lingkungan luar sistem (environment) adalah diluar batas dari sistem yang mempengaruhi operasi sistem. Lingkungan dapat bersifat menguntungkan yang harus tetap dijaga dan yang merugikan yang harus dijaga dan dikendalikan, kalau tidak akan mengganggu kelangsungan hidup dari sistem.

4. Penghubung Sistem (Interface)

Penghubung sistem merupakan media penghubung antara satu subsistem dengan subsistem lainnya. Melalui penghubung ini memungkinkan sumber-sumber daya mengalir dari subsistem ke subsistem lain. Keluaran (output) dari subsistem akan menjadi masukkan (input) untuk subsistem lain melalui penghubung.

5. Masukkan Sistem (Input)

Masukkan adalah energi yang dimasukkan kedalam sistem, yang dapat berupa perawatan (maintenance input) dan masukkan sinyal (signal input). Maintenance input adalah energi yang dimasukkan agar sistem dapat beroperasi. Signal input adalah energi yang diproses untuk didapatkan keluaran. Contoh dalam sistem komputer program adalah maintenance input sedangkan data adalah signal input untuk diolah menjadi informasi.

6. Keluaran Sistem (Output)

Keluaran sistem adalah hasil dari energi yang diolah dan diklasifikasikan menjadi keluaran yang berguna dan sisa pembuangan. Contoh komputer menghasilkan panas yang merupakan sisa pembuangan, sedangkan informasi adalah keluaran yang dibutuhkan.

7. Pengolah Sistem

Suatu sistem menjadi bagian pengolah yang akan merubah masukkan menjadi keluaran. Sistem produksi akan mengolah bahan baku menjadi bahan jadi, system akuntansi akan mengolah data menjadi laporan-laporan keuangan.

8. Sasaran Sistem

Suatu sistem pasti mempunyai tujuan (goal) atau sasaran (objective). Sasaran dari sistem sangat menentukan input yang dibutuhkan sistem dan keluaran yang akan dihasilkan sistem.

\section{2.2 Sistem Informasi}

Sistem informasi adalah suatu sistem didalam suatu organisasi yang mempertemukan kebutuhan pengelolaan transaksi harian, mendukung operasi, bersifat manajerial dan kegiatan strategi dari suatu organisasi dan menyediakan pihak luar tertentu dengan laporan-laporan yang dibutuhkan [6].

Sistem informasi merupakan suatu sistem di dalam suatu organisasi yang mempertemukan kebutuhan pengolahan transaksi harian yang mendukung fungsi operai organisasi yang bersifat manajerial dengan kegiatan strategi dari suatu organisasi untuk dapat menyediakan laporan-laporan yang diperlukan oleh pihak luar tertentu [9]. Sistem informasi adalah suatu sistem didalam suatu organisasi yang mempertemukan kebutuhan pengolahan transaksi harian, mendukung operasi bersifat manajerial dan kegiatan strategis dari suatu organisasi dan menyediakan pihak luar tertentu dengan laporan-laporan yang diperlukan [7].

JSIKTI Vol. 2, No. 2, Desember 2019: $77-88$ 


\subsubsection{Sistem Informasi Akuntansi}

Akuntansi merupakan bahasa dari bisnis. Setiap perusahaan menerapkannya sebagai alat komunikasi. Secara klasik akuntansi merupakan proses pencatatan (recording), pengelompokan (classifying), perangkuman (summarizing) dan pelaporan (reporting) dari kegiatan transaksi perusahaan. Tujuan akhir dari kegiatan akuntansi adalah penerbitan laporanlaporan keuangan. Laporan-laporan keuangan adalah suatu informasi. Sistem informasi yang berbasis komputer sekarang dikenal dengan istilah sistem informasi akuntansi atau SIA (Accounting Information System atau AIS).

Menurut Wijayanto, Sistem Informasi Akuntansi adalah susunan berbagai dokumen, alat komunikasi, tenaga pelaksana dan berbagai laporan yang didesain untuk mentransformasikan data keuangan menjadi informasi keuangan, sedangkan menurut Rommey, Sistem Informasi Akuntansi adalah sumber daya manusia dan modal dalam organisasi yangbertanggung jawab untuk persiapan keuangan dan informasi yang diperoleh dari mengumpulkan dan memproses berbagai transaksi perusahaan [10].

\section{2.4 Proses dan Siklus Akuntansi}

Siklus akuntansi yaitu proses dari tiga aktivitas yaitu : mengidentifikasi, mencatat, dan mengkomunikasikan kejadian ekonomi dari sebuah organisasi. Proses pertama adalah identifikasi, yaitu aktifitas memilih kegiatan yang termasuk kegiatan ekonomi. Proses kedua adalah pencatatan, yaitu semua kegiatan ekonomi tersebut dicatat untuk menyediakan sejarah dari kegiatan keuangan dari organisasi tersebut. Proses ketiga adalah komunikasi, informasi yang telah didapat dari identifikasi dan pencatatan tidak akan berguna bila tidak dikomunikasikan. Informasi ini dikomunikasikan melalui persiapan dan distribusi dari laporan akuntansi, yang paling umum, disebut dengan laporan keuangan. Sistem informasi akuntansi tidak lepas dari siklus akuntansi yang meliputi urutan siklus bahwa semua transaksi harus dicatat dalam jurnal dan kemuadian secara periodic dibukukan kedalam rekening-rekening dibuku besar. Pada akhir periode saldo-saldo dari semua rekening dihitung dan dicantumkan dalam neraca lajur sebagai alat bantu untuk menyusun laporan-laporan keuangan, jurnal penyesuaian, dan jurnal penutup juga dilaksanakan dalam perusahaan dagang, begitu pula halnya pembuatan neraca saldo setelah tutup buku perlu dikerjakan sebagai taraf akhir dalam siklus akuntansi [11].

\subsubsection{Pengujian Black Box Testing}

Pengujian black-box testing (pengujian kotak hitam) yaitu menguji perangkat lunak dari segi spesifikasi fungsional tanpa menguji desain dan kode program[12]. Pengujian ini dimaksudkan untuk mengetahui apakah fungsi-fungsi, masukan dan keluaran dari perangkat lunak sesuai dengan spesifikasi yang dibutuhkan.

Pengujian kotak hitam dilakukann dengan membuat kasus uji yang bersifat mencoba semua fungsi dengan memakai perangkat lunak apakah sesuai dengan spesifikasi yang dibutuhkan. Kasus uji yang dibuat untuk melakukan pengujian kotak hitam harus dibuat dengan kasus benar dan kasus salah, misalkan untuk kasus proses login maka kasus uji yang dibuat adalah:

- Jika user memasukkan nama pemakai (username) dan kata sandi (password) yang benar

- Jika user memasukkan nama pemakai (username) dan kata sandi (password) yang salah, misalnya nama pemakai benar tapi kata sandi salah atau sebaliknya atau keduanya salah.

Pengujian black-box testing berfokus pada persyaratan fungsional Perangkat Lunak [13]. Pengujian ini memungkinkan analisis sistem memperoleh kumpulan kondisi input yang akan mengerjakan seluruh keperluan fungsional program. Tujuan metode ini mencari kesalahan pada [13]:

1. Fungsi yang salah atau hilang.

2. Kesalahan pada interface. 
3. Kesalahan pada struktur data atau akses database.

\subsection{Gambaran Umum Sistem}

Sistem yang akan dibuat adalah sistem informasi akuntansi pada perangkat berbasis web. Pengguna dari sistem ini ialah pimpinan atau pemilik dari perusahaan. Sistem ini akan mengelola transaksi pemasukan, transaski pengeluaran, mengelola laporan dan menghasilkan laporan jurnal umum, laporan neraca, laba rugi dan laporan perubahan modal. Gambar 1 di bawah ini merupakan gambaran umum sistem yang akan dibuat.

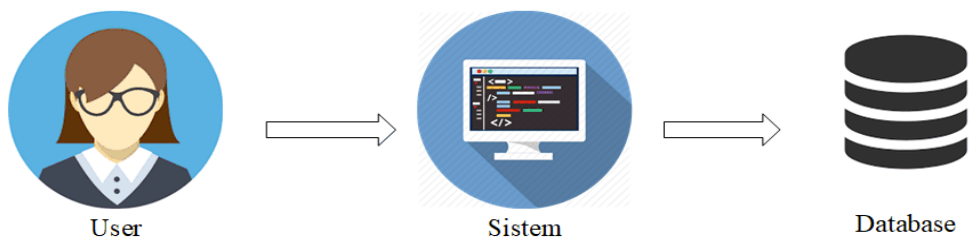

Gambar 1 Gambaran Umum Sistem

Dari gambar dapat dilihat bahwa user akan melakukan penginputan data keuangan dan akan diproses oleh sistem. Semua proses akan tersimpan kedalam database dan akan menghasilkan output berupa laporan. Dalam hal ini user merupakan pemilik perusahaan dan karyawan dan sistem merupakan sistem informasi akuntansi.

Pada penelitian ini menggunakan perancangan aplikasi UML (Unified Modeling Language) yang merupakan sekumpulan alat yang digunkan untuk melakukan abstraksi terhadap sebuah sistem atau perangkat lunak berbasis objek. Perancangan aplikasi UML juga menjadi salah satu cara untuk mempermudah pengembangan aplikasi yang berkelanjutan. Aplikasi atau sistem yang tidak terdokumentasi biasanya dapat menghambat pengembangan karena developer harus melakukan dan mempelajari kode program.

UML juga dapat menjadi alat bantu untuk transfer ilmu tentang sistem atau aplikasi yang akan dikembangkan dari satu developer ke developer lainnya. Dengan adanya UML, bukan hanya antar developer yang dapat memahami sebuah sistem melainkan orang bisnis dan siapapun dapat memahami sebuah sistem. Dalam perancangan UML terdapat empat (4) tahap yaitu Use Case Diagram, Activity Diagram, Sequence diagram dan Class Diagram.

\subsubsection{Use Case Diagram}

Use case diagram dalam penelitian ini telah dideskripsikan pada gambar dibawah ini. Pada gambar dapat dijelaskan bahwa terdapat satu aktor yang dimana aktor tersebut merupakan pemilik perusahaan. Perilaku dari pemilik perusahaan yaitu mengelola pemasukan, mengelola pengeluaran, mengelola akun, mengelola kategori dan mengelola laporan. Perilaku tersebut dapat dilakukan jika pemilik sudah melakukan proses login dan pemilik juga bisa melakukan pencetakan laporan jika diperlukan, seperti pada Gambar 2.

\subsubsection{Activity Diagram}

Activity diagram berfungsi untuk menggambarkan setiap aliran kerja (workflow) atau aktivitas sistem pada aplikasi. Activity diagram pada sistem dapat dilihat sebagai berikut ; Gambar 3 di bawah ini merupakan activity diagram dari login. Apabila pemilik dan karyawan melakukan login dengan cara memasukkan nama pengguna dan kata sandi dan kemudian mengklik button login/masuk untuk masuk ke sistem. Selanjutnya sistem akan melakukan validasi login dan jika proses login sukses maka selanjutnya sistem akan mengarahkan pada halaman utama. Halaman utama disini ialah halaman dashboard dan apabila proses login gagal maka sistem akan menampilkan halaman login/masuk. Akan tetapi, dalam proses login ini terdapat hak akses dari pemilik dan karawan yan dimana pemilik dapat mengakses dashboard, data akun, kategori, transaksi, dan laporan. Sedangkan untuk karyawan hanya dapat mengakses dashboard, transaksi dan laporan.

JSIKTI Vol. 2, No. 2, Desember 2019: $77-88$ 


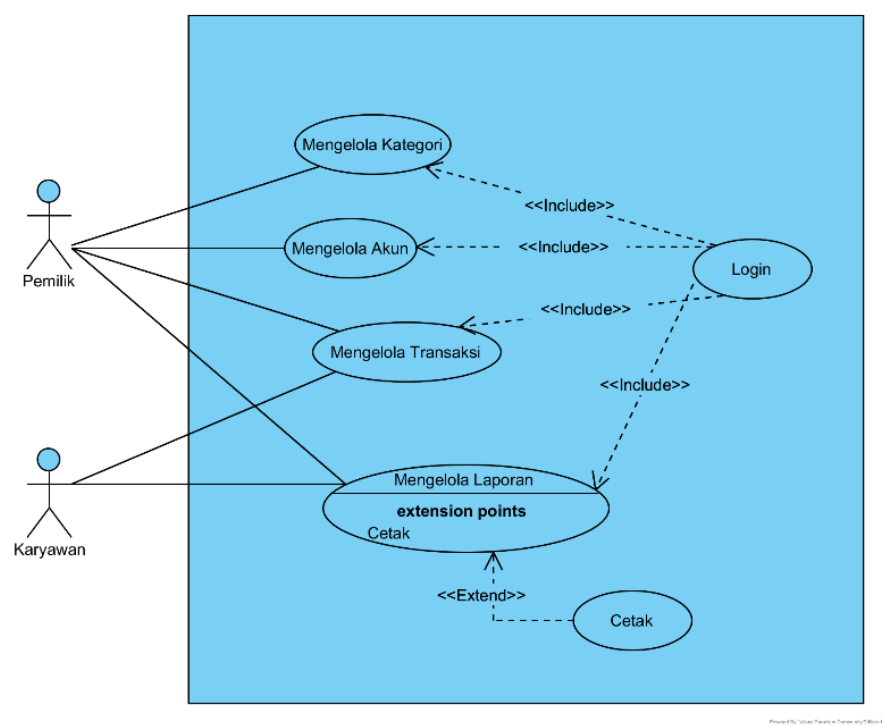

Gambar 2 Use Case Diagram Sistem Informasi Keuangan

Activity diagram berfungsi untuk menggambarkan setiap aliran kerja (workflow) atau aktivitas sistem pada aplikasi.

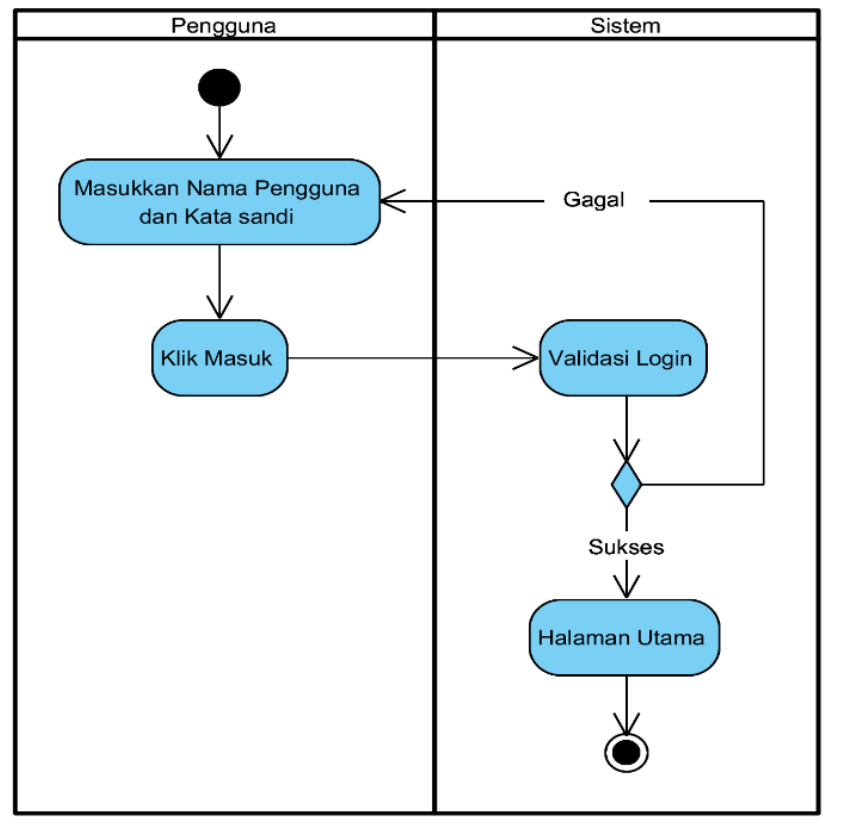

Gambar 3 Activity Diagram Login

\subsubsection{Sequence Diagram}

Sequence diagram menggambarkan tentang interaksi antar objek di dalam dan sekitar sistem aplikasi. Berikut merupakan sequence yang ada dalam penelitian ini.

- Sequence Diagram login/Masuk

Pada proses login terdapat dua sequence yang menjelaskan tentang alur login sukses dan alur gagal login, berikut merupakan penjelasan dari kedua alur tesebut.

- Sequence Diagram Sukses Login

Pada Gambar 4 dapat dilihat bahwa terdapat aktor pengguna yang malakukan interaksi dengan form login untuk memasukkan username atau nama pengguna dan memasukkan password atau kata sandi. Selanjutnya akan diteruskan pada control login untuk melakukan 
pengecekan pada tabel login dan jika username dan password yang dimasukkan benar maka tabel akan mengirimkan pesan pada control user.

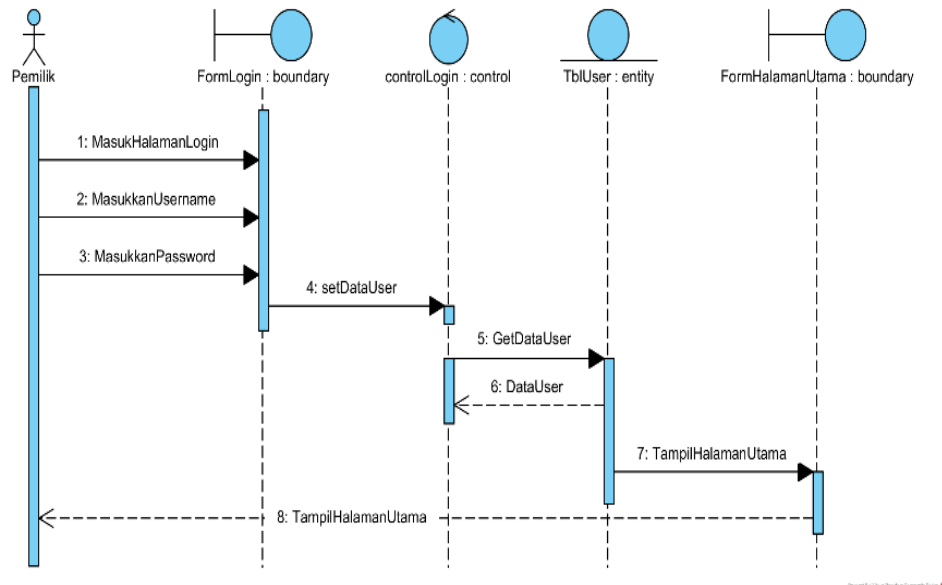

Gambar 4 Sequence Diagram Sukses Login

\subsection{Form Halaman Utama}

Gambar 5 merupakan form halaman utama yang akan ditampilkan apabila yang sukses melakukan login ialah owner dari STIKI Copy Center.

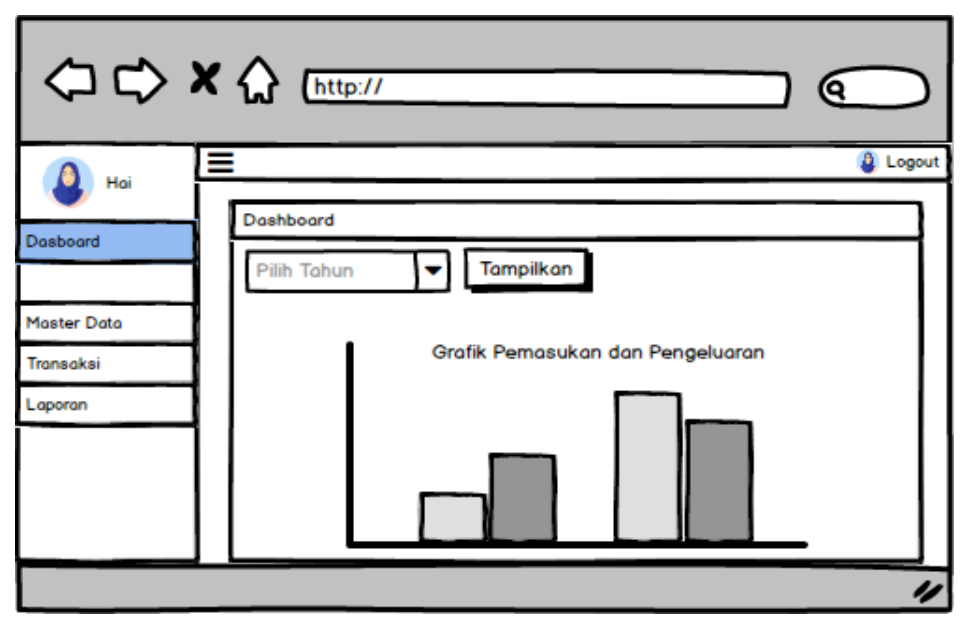

Gambar 5Tampilan Halaman Utama/Dashboard Owner

Tampilan form laporan perubahan modal dapat dilihat pada Gambar 6 di bawah ini.

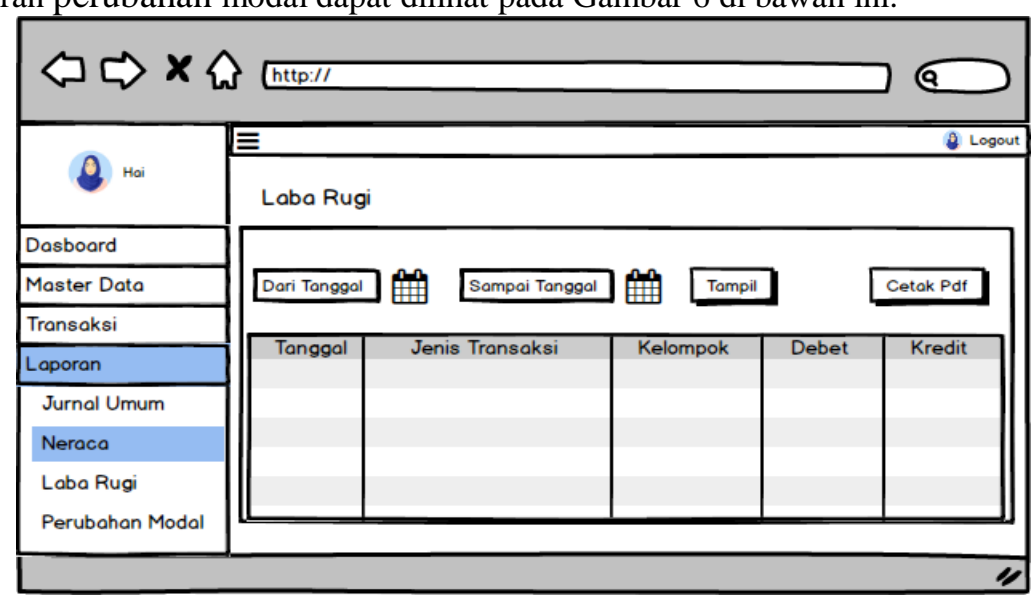

Gambar 6 Tampilan Laporan Perubahan Modal

JSIKTI Vol. 2, No. 2, Desember 2019: $77-88$ 


\subsection{Skenario Pengujian}

Skenario pengujian dilakukan untuk mengetahui apakah sistem yang dirancang akan berjalan dengan baik atau tidak. Pengujian yang dilakukan pada sistem ini menggunakan pengujian black box testing, yang dimana dalam pengujian ini terfokus pada fungsi yang terdapat pada aplikasi. Berikut ini merupakan penjelasan dari skenario pengujian black box yang dilakukan oleh penulis. Skenario Pengujian Form Login (Masuk), Pengujian yang dilakukan pada proses login (masuk) adalah untuk mengetahui semua fungsi login dapat berjalan dengan baik dan benar. Berikut merupakan tabel skenario pengujian login yang ditunjukkan pada Tabel 1.

Tabel 1 Skenario Pengujian Halaman Masuk (Login)

\begin{tabular}{|c|c|c|}
\hline No & Skenario Pengujian & Hasil yang Diharapkan \\
\hline 1 & \begin{tabular}{llr}
\multicolumn{2}{l}{ Memasukkan nama } \\
pengguna sesuai dengan \\
hak akses.
\end{tabular} & $\begin{array}{l}\text { Sistem akan menampilkan pesan "sukses" dan } \\
\text { mengarahkan pada halaman dashboard sesuai } \\
\text { dengan hak akses. }\end{array}$ \\
\hline 2 & $\begin{array}{l}\text { Memasukkan } \\
\text { pengguna dan kata sandi } \\
\text { yang salah, klik tombol } \\
\text { masuk. }\end{array}$ & $\begin{array}{l}\text { Sistem menampilkan pesan "gagal, nama } \\
\text { pengguna dan kata sandi yang dimasukkan tidak } \\
\text { cocok atau salah". }\end{array}$ \\
\hline 3 & $\begin{array}{ll}\text { Memasukkan } & \text { salah satu } \\
\text { inputan data, } & \text { selanjutnya } \\
\text { klik login. } & \end{array}$ & $\begin{array}{l}\text { Sistem akan menampilkan pesan data tidak boleh } \\
\text { kosong. }\end{array}$ \\
\hline
\end{tabular}

\section{HASIL DAN PEMBAHASAN}

Tahap implementasi sistem merupakan tahap penerapan sistem berdasarkan hasil mekanisme perancangan yang telah dilakukan. Pada tahap implementasi dilakukan pengujian fungsional agar dapat dioperasikan secara optimal sesuai dengan kebutuhan. Implementasi sistem akan dibatasi sesuai dengan perancangan dan analisis yang telah dilakukan yang meliputi

1. Sisi Owner

Pada sisi owner memiliki tampilan berdasarkan hak akses owner. Adapun implementasinya meliputi login, mengelola master data yaitu mengelola data akun dan data kategori, mengelola transaksi dan juga dapat melakukan pencetakan laporan serta melakukan logout.

2. Sisi Karyawan

Pada sisi karyawan memiliki beberapa hak akses yang meliputi login, mengelola transaksi dan melakukan pencetakan laporan..

\subsection{Halaman Login}

Pada halaman ini karyawan maupun owner dapat menginputkan username dan password sebelum masuk dan mengelola sistem. Jika username dan password yang diinputkan benar maka akan diarahkan pada halaman dashboard pada sistem yang disertakan dengan pesan sukses login. Gambar 7 merupakan tampilan halaman login Sistem Informasi Akuntansi.

Dari gambar 7 terlihat sedikit berbeda dengan tampilan yang terdapat pada gambar lainnya. Adapun perbedaannya terletak pada menu sidebar. Pada hak akses admin atau owner dapat mengakses master data yang didalamnya terdapat dua menu yaitu data akun dan data kategori. Sedangkan untuk karyawan hanya bisa mengakses dashboard, transaksi dan menu laporan. 


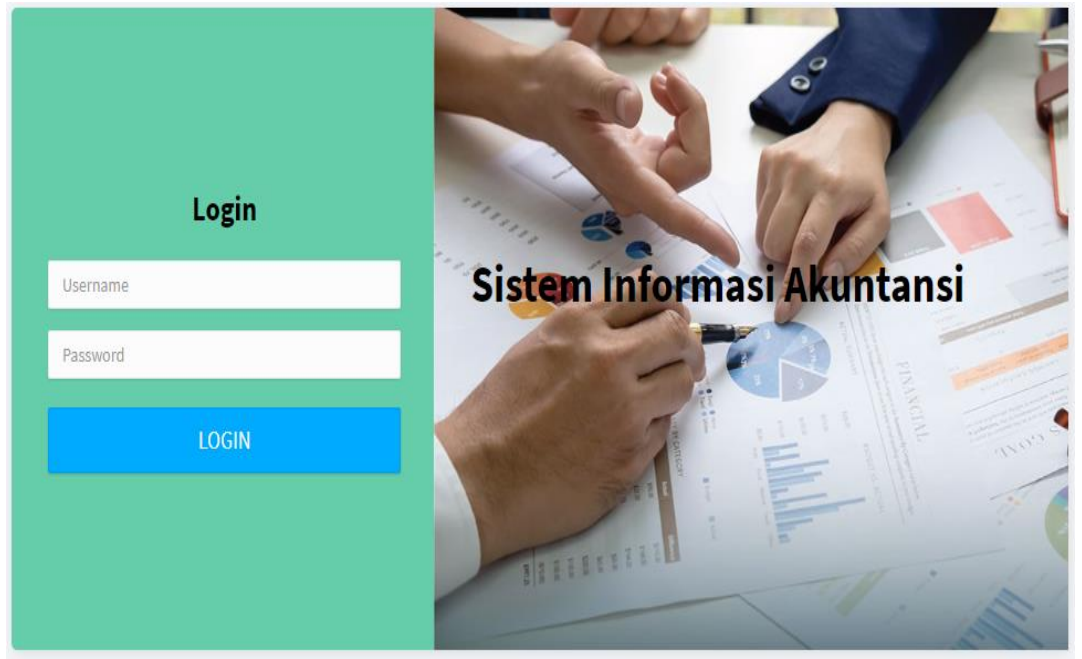

Gambar 7 Halaman Login

\subsection{Tampilan Dashboard}

Tampilan ini akan muncul pertama kali jika telah melakukan login. Adapun yang ada pada tampilan ini ialah grafik pemasukan dan pengeluaran yang ditampilkan setiap bulannya. Berikut merupakan gambar dari tampilan dashboard.

Gambar 8 merupakan gambar dari tampilan dashboard untuk hak akses owner, dari tampilannya sendiri dapat dilihat bahwa pada menu sidebar yang terdapat menu master data yang didalamnya terdapat menu data akun dan data kategori, terdapat menu transaksi dan laporan

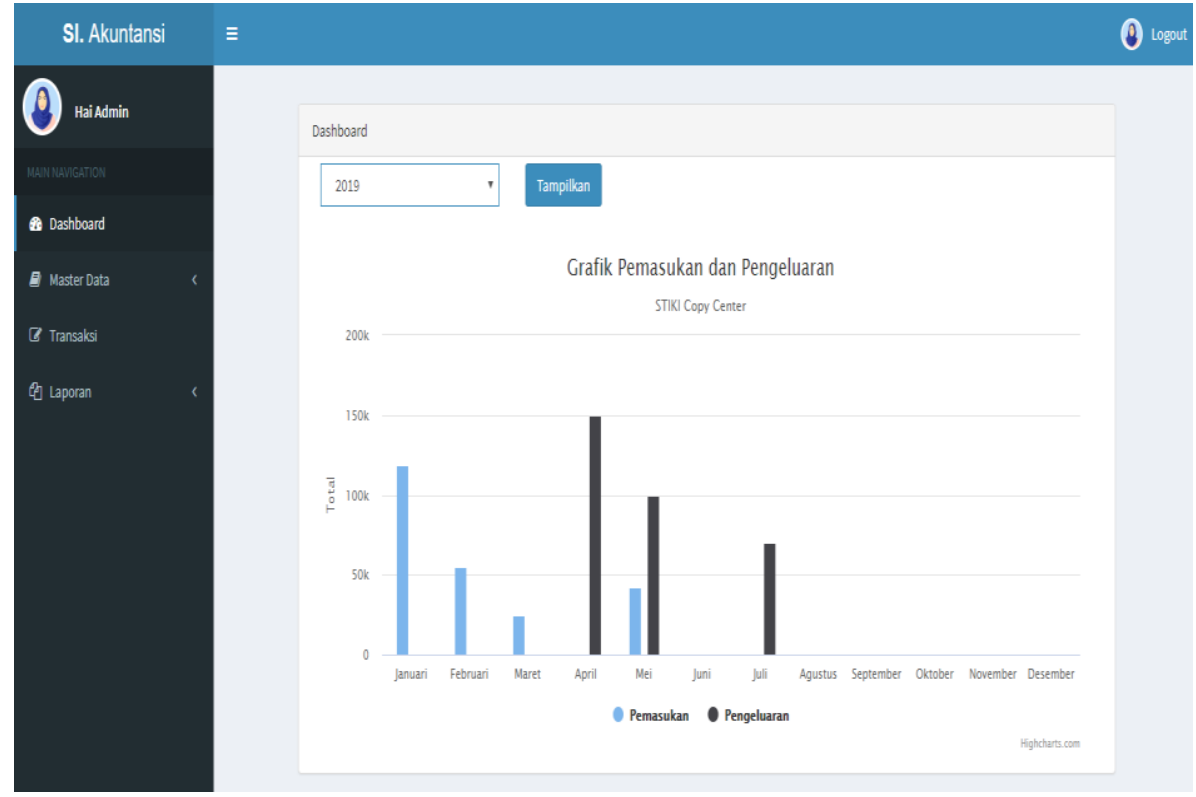

Gambar 8 Tampilan Dashboard Hak Akses Owner

\subsection{Tampilan Tambah Data Akun}

Untuk melakukan tambah data akun, pengguna dapat mengklik button tambah data dan sistem akan menampilkan form untuk melakukan penambahan data akun. Pada form tambah data akun terdapat inputan data akun yang sudah terisi secara otomatis dan nama akun yang wajib untuk diisi dan juga terdapat button simpan untuk menyimpan data dan button batal untuk membatalkan penyimpanan dan penginputan data. Setelah melakukan penyimpanan data maka sistem akan mengarahkan kembali ke tampilan awal dari data akun. Untuk lebih jelas lagi tentang tampilan tambah data akun dapat dilihat pada Gambar 9. 


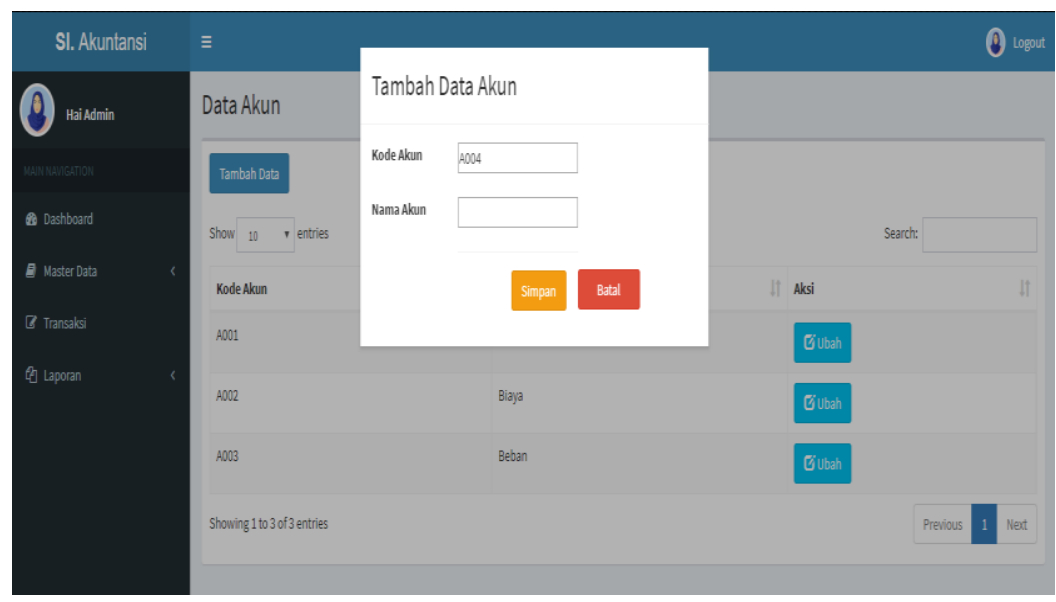

Gambar 9 Tambah Data Akun

\section{KESIMPULAN}

Berdasarkan penelitian yang dilakukan dengan merancang, membangun dan menguji Sistem informasi Akuntansi di STIKI Copy Center dapat diambil kesimpulannya sebagai berikut. Proses perancangan Sistem Informasi Akuntansi di STIKI Copy Center diawali dengan melakukan pengumpulan data-data berupa data transaksi penjualan, data laporan keuangan sederhana dan data yang dilakukan dengan wawancara yang diperlukan dalam proses pembuatan perancangan dan pembangunan sistem informasi keuangan. Adapun laporan keuangan yang dihasilkan dari Sistem Informasi Akuntansi di STIKI Copy Center ialah laporan jurnal umum, laporan neraca, laporan laba rugi dan laporan perubahan modal. Pengujian blackbox yang telah dilakukan dengan sembilan pengujian dengan empat puluh satu skenario pengujian yang dilakukan, didapatkan hasil bahwa fitur - fitur yang terdapat pada Sistem Informasi Akuntansi di STIKI Copy Center dapat berjalan dengan baik sesuai dengan yang diharapkan.

\section{SARAN}

Berdasarkan uraian dari kesimpulan yang penulis paparkan, penulis sangat menyadari bahwa masih perlu adanya penyempurnaan dari sistem informasi ini. Berikut saran yang penulis usulkan untuk pengembangan penelitian. Pada pengembangan sistem informasi akuntansi selanjutnya diharapkan peneliti dapat membuat sistem yang lebih terperinci dengan membuat buku besar dan jurnal penyesuaian. Untuk penelitian selanjutnya penulis juga menyarankan untuk mengembangkan sistem yang lebih responsive.

\section{DAFTAR PUSTAKA}

[1] Putra, I. W. C. R, "Sistem Informasi Laporan Keuangan Pada Hattrick Center Berbasis Web”, Denpasar : STMIK STIKOM Indonesia, 2018.

[2] Setyadevi, A. L, "Rancang Bangun Sistem Informasi Pengelolaan Keuangan Pada CV. Sinar Surya Transportasi Berbasis Website", Denpasar: STMIK STIKOM Indonesia, 2018.

[3] Sutabri, T., “Analisis Sistem Informasi”. Yogyakarta: CV. Andi Offset, 2018. 
[4] A. Mauko, B. Muslimin, and P. Sugiartawan, "Sistem Pendukung Keputusan Kelompok Dalam Pemilihan Saham Indeks LQ 45 Menggunakan Metode,” J. Sist. Inf. dan Komput. Terap. Indones., vol. 1, no. 1, pp. 25-34, 2018.

[5] I. Pratistha, P. Sugiartawan, U. G. Mada, M. Manajemen, and U. G. Mada, "Sistem Pendukung Keputusan Kelompok Pemilihan E-Commerrce Menggunakan Metode Profile Matching dan BORDA," vol. 1, no. 1, 2018.A. Mauko, B. Muslimin, and P. Sugiartawan, "Sistem Pendukung Keputusan Kelompok Dalam Pemilihan Saham Indeks LQ 45 Menggunakan Metode,” J. Sist. Inf. dan Komput. Terap. Indones., vol. 1, no. 1, pp. 2534, 2018.

[6] Hutahaean, J, “Konsep Sistem Informasi”, Yogyakarta : Penerbit Deepublish, 2014

[7] Jogiyanto, "Sistem Teknologi Informasi". Yogyakarta: Andi, 2005.

[8] Jogiyanto, "Analisis dan Desain Sistem Informasi: Pendekatan Terstruktur Teori dan Praktek Aplikasi Bisnis". Yogyakarta : Andi, 2008.

[9] Sutabri, T, Analisis Sistem Informasi. Yogyakarta: CV. Andi Offset, 2012

[10] Mardi, “Sistem Informasi Akuntansi”. Jakarta : Ghalia Indonesia, 2011.

[11] Jusup, H., "Dasar-dasar Akuntansi Jilid 2" Edisi 7. Yogyakarta: Sekolah Tinggi Ilmu Ekonomi YKPN, Yogyakarta, 2011.

[12] Shalahuddin, R., "Rekayasa Perangkat Lunak Terstruktur Dan Berorientasi Objek", Bandung: Informatika Bandung, 2018.

[13] Maturidi, A. D, “Metode Penelitian Teknik Informatika”, Yogyakarta: Deepublish, 2012.

JSIKTI Vol. 2, No. 2, Desember 2019: $77-88$ 